\title{
Role of Genetic Polymorphism of Angiotensin-Converting Enzyme, Plasminogen Activator Inhibitor-1 and Endothelial Nitric Oxide Synthase in the Prognosis of Coronary Artery Disease
}

\author{
Ai Yuan Zhang ${ }^{\mathrm{a}, \mathrm{b}}$, Xiang Wu Ji ${ }^{\mathrm{a}}$, Ai Juan Zhang ${ }^{\mathrm{a}}$, Li Xue Guana, Jing Huang ${ }^{\mathrm{a}}$, Jing Xian Wang ${ }^{\mathrm{a}}$
}

\begin{abstract}
Background: This study was to investigate the effects of multiple genetic polymorphisms and conventional risk factors in the prognosis of coronary artery disease (CAD).

Methods: One hundred and fifty five patients with CAD were prospectively recruited, they were subgrouped as single vessel disease (SVD) and multiple vessel disease (MVD). All patients were detected I/D polymorphism of angiotensin-converting enzyme (ACE) gene, $4 \mathrm{G} / 5 \mathrm{G}$ polymorphism of plasminogen activator inhibitor-1 (PAI-1) gene, and G894 $\rightarrow$ T mutation of endothelial nitric oxide synthase (eNOS) gene. The patients were followed up for 10-65 months, mean 35 months. End points were major adverse cardiovascular events (MACE), including angina, myocardial infarction, and cardiac sudden death.
\end{abstract}

Results: During the follow-up period, MACE developed in 81 patients, 73 patients with angina, seven with myocardial infarction, and one with cardiac sudden death. CAD patients with MVD were more probable of developing MACE during follow-up. Distribution of PAI-1 gene polymorphism was significantly different between SVD and MVD patients, $\mathrm{p}<0.001$. The frequency of DD genotype of $\mathrm{ACE}$ and $4 \mathrm{G} / 4 \mathrm{G}$ genotype of PAI-1 in patients with MACE were significantly higher than those in patients without MACE, $\mathrm{p}<0.001$ and $p=0.002$, respectively. Incidence of diabetes mellitus was significantly higher in patients with MACE than in patients without MACE, $P=0.03$. Cox regression analysis showed that diabetes mellitus (HR 2.36, 95\% CI 1.33-4.46, $\mathrm{p}=0.003$ ), 4G/4G polymorphism of PAI-1 gene (HR 3.45, 95\% CI 1.71-6.56, $\mathrm{p}=0.009$ ), and $\mathrm{D} / \mathrm{D}$ polymorphism of ACE gene (HR 2.99, 95\% CI 1.84-5.76, $\mathrm{p}=$ $0.005)$, were independent predictors of the MACE.

\footnotetext{
Manuscript accepted for publication December 1, 2010

a'Department of Cardiology, Affiliated Wei Fang People's Hospital of Wei Fang Medical College, Wei Fang, Shandong Province, China

${ }^{b}$ Corresponding author: zhangaiyuan@yahoo.com.cn
}

doi:10.4021/cr108e
Conclusions: Our results showed that the conventional risk factors and genetic polymorphisms have significant influence on prognosis of CAD patients. CAD patients with diabetes mellitus, DD genotype of $\mathrm{ACE}$, and $4 \mathrm{G} / 4 \mathrm{G}$ genotype of PAI-1 suggested poor prognosis.

Keywords: Coronary artery disease; Gene polymorphism; Angiotensin-converting enzyme; Endothelial nitric oxide synthase; Plasminogen activator inhibitor-1; Prognosis; Major adverse cardiovascular event

\section{Introduction}

Coronary artery disease (CAD) can be caused by multiple factors from conventional and genetical aspects, and these factors are interactive [1-4]. Several genetic systems are involved in the pathophysiology of CAD, among these, angiotensin I-converting enzyme (ACE) plays role in modulating vascular tone and electrolyte balance by hydrolyzing angiotensin I to angiotensin II, which is a potent vasopressor and aldosterone-stimulating peptide [5], the individual variation of plasma ACE levels is largely affected by polymorphism of the ACE gene. Previous studies showed that the I/D polymorphism of ACE is highly related to the coronary artery disease (CAD), the DD genetic type is the independent risk factor of CAD [6-8].

It has been shown that endothelial nitric oxide synthase (eNOS) inhibition can accelerate atherosclerosis in animal models, the abnormalities in the eNOS pathway are present in humans with atherosclerosis [9]. Therefore, functional variants of the eNOS gene could influence individual susceptibility to atherosclerosis by altering the amount of NO generated by the endothelium. Among the several polymorphisms of the eNOS gene, the common variant located in exon $7(\mathrm{G} 894 \rightarrow \mathrm{T})$ that modifies its coding sequence (Glu298 $\rightarrow$ Asp) has been linked to the risk for coronary artery spasm, and acute myocardial infarction (AMI) $[10,11]$. 
The plasminogen activator inhibitor-1(PAI-1) 4G/5G polymorphism is also related to $\mathrm{CAD}$, the carriers of $4 \mathrm{G} / 4 \mathrm{G}$ allele have high incidence of CAD [12], they are susceptible to $\mathrm{CAD}$ under the same conventional factors.

The interactive effects of aforementioned genes polymorphism on the clinical features and prognosis of CAD are not fully elucidated. Studies including these three important genes polymorphism encompassing three pathophysiological pathways on CAD severity and prognosis are rare. In this study, we investigated the prevalence and interaction of these pathway genes polymorphims, and their interaction with conventional risk factors in the severity and prognosis of CAD in Chinese population.

\section{Materials and Methods}

\section{Study population}

Study subjects were prospectively recruited from April 2001 to November 2005, all patients were diagnosed as CAD by quantitative coronary angiography, with more than $50 \%$ luminal diameter stenosis affecting at least one coronary vessel.

The study subjects were stratified into two subgroups according to the number of diseased major vessels (left anterior descending, left circumflex, and right coronary artery and their major branches) as single vessel disease (SVD) and multiple vessel disease (MVD) which affected more than one vessels. If only the left main coronary was affected, it was recorded as MVD.

Medical histories of hypertension, diabetes mellitus and cigarette smoking were obtained. Hypertension was diagnosed when elevated blood pressure $(>140 / 90 \mathrm{mmHg})$ was measured on 3 occasions or were already being treated with antihypertensive agents. Diabetes mellitus was defined as having a fasting blood glucose level of $>7.0 \mathrm{mmol} / \mathrm{L}$ on at least two separate occasions, or was already receiving treatment for diabetes. Subjects with cardiomyopathy, congenital heart disease, renal or hepatic disease, valvular disease, were excluded from the study. One hundred and ninety healthy controls were recruited consecutively from those who were admitted to our hospital for routine health examination during the same period. These controls had no histories of coronary artery disease, cerebrovascular disease or peripheral arterial disease.

All subjects in study and control groups were from the Chinese Han population, they were genetically unrelated. This study protocol was approved by the bioethical committee of Weifang people's hospital, and was in accordance with the Declaration of Helsinki. Informed consent was obtained from every participant.

\section{Genotyping}

Genomic DNA was prepared from samples of whole blood by standard methods. Peripheral blood leukocyte DNA was extracted, genotypes were assessed by PCR-based method.

PCR assay for I/D polymorphism of the ACE gene was performed as previously described [13], 0.1 lag genomic DNA was amplified with a forward primer (5'-CTGCAGACCACTCCCATCCTTTCT-3'), a reverse primer (5'-GATGTGGCCATCACATTCGTCAGAT-3').

PCR assay for Glu298-Asp polymorphism in exon 7 of Enos was performed as previoiusly described [10], 0.1 lag genomic DNA was amplified with a forward primer (5'-CATGAGGCTCAGCCCCAGAAC-3'), a reverse primer (5'-AGTCAATCCCTTTGGTGCTCAC-3').

PCR assay for $4 \mathrm{G} / 5 \mathrm{G}$ polymorphism of the PAI- 1 gene was performed as previoiusly described [14, 15], 0.1 lag genomic DNA was amplified with a forward primer (5'-CAC AGA GAG AGT CTG GCC ACGT -3'), a reverse primer (5'-CAG CCA CTG GAT TGT CTA GGT-3').

Amplification was performed in a final volume of $25 \mu \mathrm{l}$ containing $0.75 \mu \mathrm{mol}$ of each primer, $1.2 \mathrm{mmol} / \mathrm{L} \mathrm{MgC1}_{2}, 50$

Table 1. Baseline Demographic and Clinical Characteristics

\begin{tabular}{|c|c|c|c|}
\hline & $\begin{array}{l}\text { CAD patients } \\
\text { n (\%) }\end{array}$ & $\begin{array}{l}\text { Control } \\
\text { n (\%) }\end{array}$ & P value \\
\hline No. of subjects & 155 & 190 & \\
\hline Age (year, mean \pm SD) & $63.7 \pm 9.8$ & $63.3 \pm 9.4$ & 0.7 \\
\hline Male/famale & $113 / 42$ & $110 / 80$ & 0.005 \\
\hline Diabetes & $35(22.5)$ & $10(5.2)$ & $<0.001$ \\
\hline Hypertension & $72(46.4)$ & $21(11)$ & $<0.001$ \\
\hline Smoking & $52(33.5)$ & $55(28.9)$ & 0.04 \\
\hline $\mathrm{TC}(\mathrm{mmol} / \mathrm{L})$ & $4.93 \pm 1.06$ & $3.6 \pm 1.3$ & $<0.001$ \\
\hline $\mathrm{TG}(\mathrm{mmol} / \mathrm{L})$ & $1.83 \pm 1.25$ & $1.5 \pm 1.2$ & 0.024 \\
\hline \multicolumn{4}{|l|}{ PAI-1 gene (4G/5G) } \\
\hline $5 \mathrm{G} 5 \mathrm{G}$ & $35(22.5)$ & $61(32,1)$ & 0.006 \\
\hline $4 \mathrm{G} 5 \mathrm{G}$ & $62(40)$ & $87(45.8)$ & \\
\hline $4 \mathrm{G} 4 \mathrm{G}$ & $58(37.5)$ & $42(22.1)$ & \\
\hline \multicolumn{4}{|l|}{ ACE gene (I/D) } \\
\hline II & 49 (31.6) & $93(48.9)$ & 0.002 \\
\hline ID & $56(36.1)$ & $61(32.1)$ & \\
\hline DD & $50(32.3)$ & $36(19)$ & \\
\hline \multicolumn{4}{|l|}{ eNOS gene } \\
\hline GG & $113(72.9)$ & $156(82.1)$ & 0.029 \\
\hline GT & $36(23.3)$ & $33(17.4)$ & \\
\hline TT & $6(3.8)$ & $1(0.5)$ & \\
\hline
\end{tabular}

TC, total cholesterol; TG, triglycerides 
$\mathrm{mmol} / \mathrm{L} \mathrm{KCl}, 10 \mathrm{mmol} / \mathrm{L}$ Tris $\mathrm{HC} 1, \mathrm{pH} 8.3,0.001 \%$ gelatin, $5 \%$ dimethylsulfoxide, $0.24 \mathrm{mmol} / \mathrm{L}$ of each $\mathrm{dNTR}$ and 1 $\mathrm{U}$ Taq polymerase. DNA amplification was achieved by an initial denaturation at $94{ }^{\circ} \mathrm{C}$ for 5 minutes, followed by 30 cycles with denaturation at $94{ }^{\circ} \mathrm{C}$ for 1 minute, annealing at $60{ }^{\circ} \mathrm{C}$ for 30 seconds, and extension at $72{ }^{\circ} \mathrm{C}$ for 30 seconds, and then final extension at $72{ }^{\circ} \mathrm{C}$ for 5 minutes. PCR products were subjected to $6 \%$ agarose gel electrophoresis.

\section{Blood biochemistry}

Blood samples were collected 6 hours after fasting, total cholesterol, triglycerides, glucose were measured using CX-9 automatic biochemistry analyzer (Beckman, Fullerton, USA ).

\section{Follow-up}

All patients received usual therapy for CAD based on the decision of the cardiologists in charge of the patients. Followup was conducted by means of telephone interview, review of medical records, and/or report from the investigators. This study cohort was followed until November 2006, end points were major adverse cardiovascular events (MACE), which include angina, myocardial infarction and cardiac sudden death. Diagnosis of myocardial infarction was based on ischemic chest symptoms, typical electrocardiographic changes, and elevation of serum creatine kinase. All events were documented on hospital records, investigator reports, and/or patients or family information.

\section{Statistics}

Data of age and biochemical variables were presented with mean value $\pm \mathrm{SD}$, and differences were compared by Student's $t$ test. Differences among the gene polymorphisms were analyzed by Chi-square test or Fisher's exact test wherever appropriate. The probability of MACE-free survival was estimated by Kaplan-Meier method, log-rank test was used to compare the MACE-free survival between SVD and MVD subtypes. Univariate and multivariate estimates of hazard ratios (HR) were calculated using the Cox regression analysis. Statistical analysis was carried out using SPSS statistical program. A value of $\mathrm{P}<0.05$ value was considered significant.

\section{Results}

\section{Baseline demographic and clinical characteristics}

During the study period, 155 patients with angiographically defined CAD were included, mean age $63.7 \pm 9.8$ years, median 67 yeas, range 25 to 79 years. Fifty-four patients were
Table 2. Baseline Clinical Characteristics and Gene Polymorphisms Between Different CAD Subtypes

\begin{tabular}{|c|c|c|c|}
\hline & $\begin{array}{l}\text { SVD } \\
\text { n (\%) }\end{array}$ & $\begin{array}{l}\text { MVD } \\
\text { n (\%) }\end{array}$ & P value \\
\hline No. of subjects & 54 & 101 & \\
\hline Age (year, mean \pm SD) & $61.7 \pm 11.8$ & $64.3 \pm 8.4$ & 0.11 \\
\hline Male/famale & $40 / 14$ & $73 / 28$ & 0.85 \\
\hline Diabetes & $11(20.3)$ & $46(45.5)$ & 0.003 \\
\hline Hypertension & $25(46.3)$ & $47(46.5)$ & 1.00 \\
\hline Smoking & $19(35.2)$ & $33(32.7)$ & 0.85 \\
\hline $\mathrm{TC}(\mathrm{mmol} / \mathrm{L})$ & $4.8 \pm 1.9$ & $4.6 \pm 1.2$ & 0.31 \\
\hline $\mathrm{TG}(\mathrm{mmol} / \mathrm{L})$ & $1.93 \pm 1.1$ & $1.7 \pm 0.9$ & 0.16 \\
\hline \multicolumn{4}{|l|}{ PAI-1 gene (4G/5G) } \\
\hline $5 \mathrm{G} 5 \mathrm{G}$ & $22(40.7)$ & $13(12.9)$ & $<0.001$ \\
\hline $4 \mathrm{G} 5 \mathrm{G}$ & $21(38.9)$ & $41(40.6)$ & \\
\hline $4 \mathrm{G} 4 \mathrm{G}$ & $11(20.4)$ & $47(46.5)$ & \\
\hline \multicolumn{4}{|l|}{ ACE gene (I/D) } \\
\hline II & $17(31.5)$ & $32(31.7)$ & 0.08 \\
\hline ID & $14(25.9)$ & $42(41.6)$ & \\
\hline DD & $23(42.6)$ & $27(26.7)$ & \\
\hline \multicolumn{4}{|l|}{ eNOS gene $(\mathrm{G} / \mathrm{T})$} \\
\hline GG & $44(81.5)$ & $69(68.3)$ & 0.09 \\
\hline $\mathrm{GT}+\mathrm{TT}$ & $10(18.5)$ & $32(31.7)$ & \\
\hline
\end{tabular}

SVD, single vessel disease; MVD, multiple vessel disease; TC, total cholesterol; TG, triglycerides.

diagnosed as SVD, 101 patients as MVD, table 1 shows the prevalence of vascular risk factors and genetic polymorphisms in patients and controls. The CAD patients had higher prevalence of hypertension, diabetes mellitus, smoking, total cholesterol and triglycerides, compared to that in the control group.

Significant difference was observed in the distribution of the PAI-1, ACE and eNOS genetic polymorphism between patients and controls, $p=0.006, p=0.002$ and $p=0.029$, respectively.

\section{Risk factors and genetic polymorphisms in SVD and MVD}

Distribution of conventional risk factors and genetic polymorphisms in SVD and MVD patients is shown in table 2. The prevalence of diabetes mellitus in MVD group was significantly higher than that in SVD group. There was no significant difference in the other conventional factors between 
Table 3. MACE Results in Different CAD Subtypes During Follow-Up

\begin{tabular}{lll}
\hline & $\begin{array}{l}\text { SVD } \\
(\mathbf{n}=\mathbf{5 4})\end{array}$ & $\begin{array}{l}\text { MVD } \\
(\mathbf{n}=\mathbf{1 0 1})\end{array}$ \\
\hline Follow-up Outcome & 24 & 49 \\
Angina & 2 & 5 \\
SCD & 0 & 1 \\
\hline
\end{tabular}

SCD, sudden cardiac death; MI, myocardial infarction.

SVD and MVD group $(\mathrm{p}=0.003)$. There was significant difference in the distribution of PAI-1 gene polymorphism between SVD and MVD patients $(\mathrm{p}<0.001)$.

\section{MACE in SVD and MVD}

The 155 CAD patients were followed up for a period of 10-65 months, the mean follow-up duration was $38 \pm 17.2$ months, median 36.5 months. MACE occurred in 81 patients, with 73 angina, seven MI, and one cardiac sudden death (Table 3). Kaplan-Meier analyis was conducted, the probability of MACE free in all patients is shown in figure 1a, the probabilities of MACE free patients in SVD and MVD are shown in figure 1b. Log-rank test showed that there was significant difference in MACE free probability between SVD and MVD group, $p=0.038$, this revealed that in the MVD group, there was higher probability of MACE development.

\section{Clinical characteristics and gene polymorphisms among patients with and without MACE during follow-up}

During follow-up period, patients with diabetes mellitus and

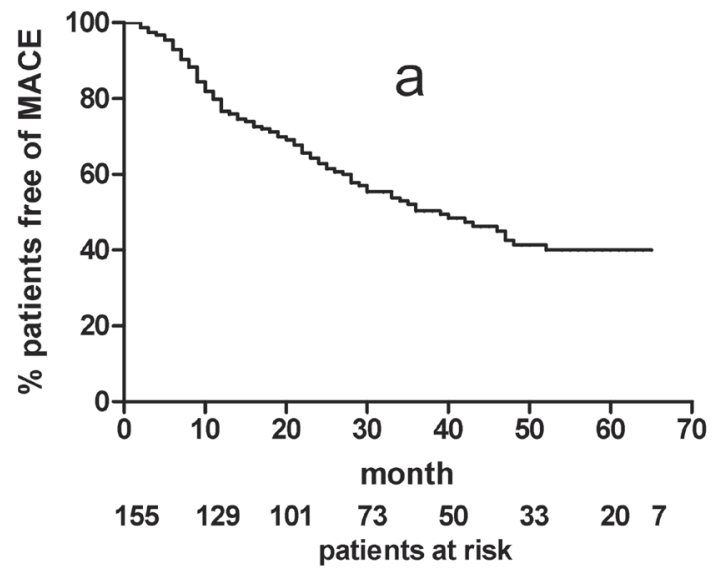

smoking showed significant high incidence of MACE, $p=$ 0.03 and $p=0.01$ respectively. The distribution of PAI-1 gene $(4 \mathrm{G} / 5 \mathrm{G})$ and ACE gene (I/D) showed significant differences between patients with and without MACE, $p<0.001$ and $\mathrm{p}=0.002$, respectively, Table 4 .

\section{Cox univariate analysis}

Table 5 summarizes the results of Cox univariate analysis. The hazard ratio of male gender was 1.22 compared with female gender, and was statistically significant, $\mathrm{p}=0.014$. The hazard ratio in patiens with diabetes mellitus or hypertension was also statistically significant compared with those without diabetes mellitus or hypertension, $p=0.002$ and $p=$ 0.01 , respectively. The hazard ratio of $4 \mathrm{G} / 4 \mathrm{G}$ polymorphism of PAI- 1 was 3.54 compared with that of $5 \mathrm{G} / 5 \mathrm{G}, \mathrm{p}<0.001$. The hazard ratio of DD polymorphism of ACE gene was 2.86 compared with that of II, $\mathrm{p}=0.003$.

\section{Cox multivariate analysis}

From the results of univariate analysis, the factors of male gender, diabetes mellitus, hypertension, $4 \mathrm{G} / 4 \mathrm{G}$ polymorphism of PAI-1 gene, and DD polymorphism of ACE gene were statistically significant, Cox multivariate analysis was carried out for these factors. The results showed that hazard ratios for diabetes mellitus, $4 \mathrm{G} / 4 \mathrm{G}$ of PAI- 1 gene and $\mathrm{DD}$ of ACE gene were high and statistically significant, $p=0.003, p$ $=0.009, p=0.005$, respectively, these three factors were the independent prognostic factors for MACE in CAD patients (Table 6).

\section{Discussion}

It has been hypothesized that a genetic component can con-

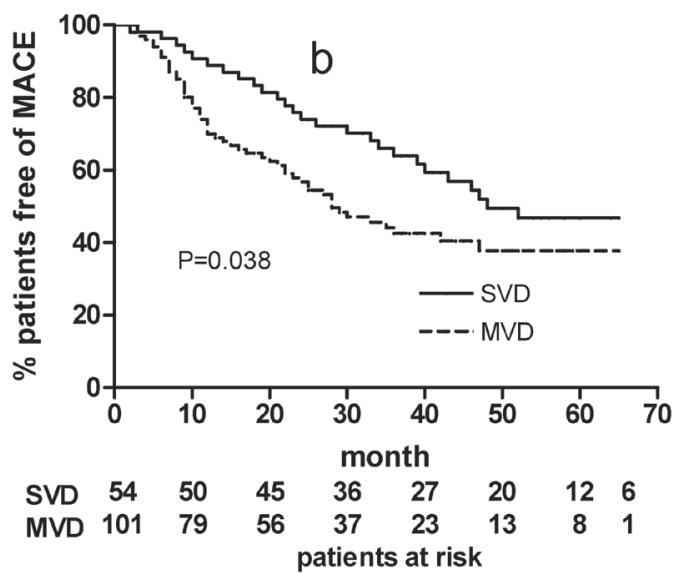

Figure 1. Kaplan-Meier analysis for probability of MACE free patients. (a) Probablility of MACE free survival in all patients. (b) Probabilities of MACE survival in SVD and MVD patients, $p=0.038$, log-rank test. 
Table 4. Clinical Characteristics and Gene Polymorphisms Among Patients With and Without MACE During Follow-up

\begin{tabular}{llll}
\hline & $\begin{array}{l}\text { With MACE } \\
\mathbf{n}(\%)\end{array}$ & $\begin{array}{l}\text { Without MACE } \\
\mathbf{n}(\%)\end{array}$ & P value \\
& & & \\
\hline & & 74 & \\
No. of subjects & 1 & $63.1 \pm 9.1$ & 0.53 \\
Age (year, mean \pm SD) & $62.1 \pm 10.8$ & $52 / 22$ & 0.59 \\
Male/famale & $61 / 20$ & $20(27)$ & 0.01 \\
Smoking & $32(39.5)$ & $11(14.9)$ & 0.03 \\
Diabetes mellitus & $24(29.6)$ & $33(44.6)$ & 0.75 \\
Hypertension & $39(48.1)$ & $4.8 \pm 1.2$ & 0.06 \\
TC (mmol/L) & $5.2 \pm 1.4$ & $1.8 \pm 1.5$ & 0.65 \\
TG (mmol/L) & $1.9 \pm 1.3$ & & \\
PAI-1 gene (4G/5G) & & $25(33.8)$ & $<0.001$ \\
$\quad$ 5G5G & $10(12.3)$ & $31(41.9)$ & \\
$\quad$ 4G5G & $31(38.3)$ & $18(24.3)$ & \\
$\quad 4 G 4 G$ & $40(49.4)$ & & 0.002 \\
ACE gene (I/D) & & $30(40.5)$ & \\
$\quad$ II & $19(23.4)$ & $30(40.5)$ & \\
ID & $26(32.1)$ & $14(19)$ & \\
DD & $36(44.5)$ & & \\
Enos gene (G/T) & & & \\
GG & $57(70.4)$ & $(75.7)$ & \\
GT+TT & $24(29.6)$ & & \\
& & & \\
\hline
\end{tabular}

MACE, major adverse cardiovascular event; TC, total cholesterol; TG, triglycerides

dition the development of CAD, in the present study, we compared the distributions of conventional risk factors and the three genetic polymorphisms (PAI-1, ACE and eNOS) in a cohort of CAD patients according to the follow-up MACE. To our knowledge, there was no such investigation before.

Our results indicated that the conventional cardiovascular risk factors presented in the CAD patients, such as smoking, hypercholesterolemia, hyperglycermia, diabetes mellitus, hypertension, were the most important risk factors in our CAD patients, smoking and diabetes mellitus were significantly associated with MACE development during follow-up.

Previous studies showed that I/D polymorphism of ACE gene was associated with $\mathrm{CAD}$, the $\mathrm{DD}$ genotype and $\mathrm{D}$ allele are the independent risk factors of CAD $[8,16]$. Survival rate of carriers with ACE DD genotype was significantly lower than that of ID and II carriers [17]. However, Larsen reported that the ACE polymorphism was not related with the CAD [18], similar results were also obtained by other researchers [19]. In our study, we found that there was no significant difference of ACE genotype distribution in SVD and MVD, however the MACE occurred more frequent in patients with DD genotype. Due to the enhanced ACE activity by $\mathrm{D}$ allele, the production of angio-tensin II is increased which enhances degradation of cardiovascular protective agent bradykinin, this results in the local blood vessel contraction and the hypertrophy of myocardiac muscle and blood vessel smooth muscle, which causes the vessel spasm and instability of coronary artery atherosclerosis plaque, then the unstable angina or MI follows.

The deletion/insertion polymorphism in the promoter region of the PAI-1 gene was identified in 1993 [20]. This polymorphism includes a "deletion" allele with a sequence of four guanosines (4G) and an "insertion" allele with five guanosines (5G) [20]. Studies showed that the $4 \mathrm{G} / 5 \mathrm{G}$ gene polymorphism was associated with a significant increase in

Table 5. Univariate Hazard Ratios by Cox Regression Analysis for the MACE

\begin{tabular}{|c|c|c|c|}
\hline Variables & $\begin{array}{l}\text { Hazard } \\
\text { ratio }\end{array}$ & $95 \% \mathrm{CI}$ & P value \\
\hline \multicolumn{4}{|l|}{ Age } \\
\hline$\leq 60$ & 1 & & \\
\hline$>60$ & 1.12 & $0.82-3.22$ & 0.36 \\
\hline \multicolumn{4}{|l|}{ Male gender } \\
\hline Female & 1 & & \\
\hline Male & 1.22 & $1.02-2.28$ & 0.014 \\
\hline \multicolumn{4}{|c|}{ Diabetes mellitus } \\
\hline No & 1 & & \\
\hline Yes & 2.57 & $1.39-5.66$ & 0.002 \\
\hline \multicolumn{4}{|l|}{ Hypertension } \\
\hline No & 1 & & \\
\hline Yes & 1.95 & $1.28-3.97$ & 0.01 \\
\hline \multicolumn{4}{|l|}{ Smoking } \\
\hline No & 1 & & \\
\hline Yes & 0.89 & $0.32-1.86$ & 0.79 \\
\hline \multicolumn{4}{|l|}{$\mathrm{TC}$} \\
\hline$\leq 5.7$ & 1 & & \\
\hline$>5.7$ & 1.23 & $0.47-2.76$ & 0.81 \\
\hline \multicolumn{4}{|l|}{ TG } \\
\hline$\leq 1.7$ & 1 & & \\
\hline$>1.7$ & 1.77 & $0.63-3.99$ & 0.57 \\
\hline \multicolumn{4}{|l|}{ PAI-1 gene } \\
\hline $5 \mathrm{G} / 5 \mathrm{G}$ & 1 & & \\
\hline $4 \mathrm{G} / 5 \mathrm{G}$ & 1.4 & $0.98-2.41$ & 0.43 \\
\hline $4 \mathrm{G} / 4 \mathrm{G}$ & 3.54 & $1.24-7.33$ & $<0.001$ \\
\hline \multicolumn{4}{|l|}{ ACE gene } \\
\hline II & 1 & & \\
\hline $\mathrm{I} / \mathrm{D}$ & 1.9 & $0.76-3.1$ & 0.32 \\
\hline DD & 2.86 & $1.64-5.89$ & 0.003 \\
\hline \multicolumn{4}{|l|}{ eNOS gene } \\
\hline GG & 1 & & \\
\hline $\mathrm{GT}+\mathrm{TT}$ & 1.28 & $0.34-2.45$ & 0.17 \\
\hline
\end{tabular}


Table 6. Multivariate Hazard Ratio by Cox Regression Analysis for the MACE Events

\begin{tabular}{llll}
\hline Variables & $\begin{array}{l}\text { Hazard } \\
\text { ratio }\end{array}$ & $\mathbf{9 5 \%}$ CI & P value \\
\hline $\begin{array}{l}\text { Male gender } \\
\text { Male }\end{array}$ & 1 & & \\
Female & 0.98 & $0.85-2.38$ & 0.32 \\
Diabetes mellitus & & & \\
No & 1 & & \\
Yes & 2.36 & $1.33-4.46$ & 0.003 \\
Hypertension & & & \\
No & 1 & & \\
Yes & 1.87 & $0.98-3.88$ & 0.12 \\
PAI-1 gene & & & \\
$\quad$ 5G5G & 1 & & \\
$\quad$ 4G5G & 1.22 & $0.88-2.12$ & 0.51 \\
$\quad$ 4G4G & 3.45 & $1.71-6.56$ & 0.009 \\
ACE gene & & & \\
II & 1 & & \\
ID & 1.82 & $0.66-2.6$ & 0.52 \\
DD & 2.99 & $1.84-5.76$ & 0.005 \\
\hline
\end{tabular}

risk of CAD and MI. Maurizio reported that the cells with 4G/4G homozygous produces more PAI-1 [21]; the 4G allele is associated with the increasing risk of CAD [22], 4G allele carriers have high risk of coronary thrombosis and sudden cardiac death, with high incidence of AMI [23, 24]. However, in other studies, no association of the PAI-I gene variation with the risk of CAD was observed $[12,25]$. In our study, we found that preverlence of $4 \mathrm{G} / 4 \mathrm{G}$ genotype significantly higher in the MACE patients, and 4G/4G genotype was more frequent in MVD than in SVD.

Several polymorphisms have been identified in the eNOS gene, among which is one located in exon $7(\mathrm{G} 894 \rightarrow \mathrm{T})$ which modifies its coding sequence $\left(\mathrm{Glu}^{298} \rightarrow\right.$ Asp). This variant has been reported to associate with coronary spasm, CAD and acute MI $[10,26]$. The homozygous of $\mathrm{Glu}^{298} \rightarrow$ Asp polymorphism might be the genetic factor of early MI, but not related with the severity of coronary artery athroserosis [11]. Variation of G894T may be the independent risk factor of coronary in-stent restenosis, the 298ASP allele carriers had higher coronary in-stent restenosis [27, 28]. Wei et al also found the mutation frenquency of eNOS gene G894 $\rightarrow$ T was not significant different among the single vessel, bi-vessel or multiple vessels CAD in Chinese Han race patients diagnosed by coronary angiography, this observation was in aggrement with ours. We found the Glu298 $\rightarrow$ Asp polymorphism of eNOS gene was not associated with MACE and severity of diseased vessels in CAD.
Cox regression multivariate analysis showed that DD polymorphism of ACE gene, $4 \mathrm{G} / 4 \mathrm{G}$ polymorphism of PAI-1 and diabetes mellitus are independent prognostic risk factors of CAD. The genetic susceptible individuals can be instructed to control the conventional risk factors in order to prevent or treat the CAD in early stage.

In conclusion, CAD patients carrying DD genotype of ACE gene are susceptible of MACE. CAD patients carrying 4G/4G genotype of PAI-1 gene are susceptible of multiple vessel disease and MACE during follow-up. The DD polymorphism of ACE gene, $4 \mathrm{G} / 4 \mathrm{G}$ polymorphism of PAI-1 gene as well as diabetes mellitus, are the independent prognostic factors of CAD.

\section{Acknowledgement}

This study was supported by the Key Scientific Research Program of Shandong Province of China (No. 2004GG2202040), and by the Wu Jie Ping Fundation of China (No. 15-A, 2003). The authors have no conflict interests to declare.

\section{References}

1. Nordlie MA, Wold LE, Kloner RA. Genetic contributors toward increased risk for ischemic heart disease. J Mol Cell Cardiol 2005;39(4):667-679.

2. Watson KE, Topol EJ. Pathobiology of atherosclerosis: are there racial and ethnic differences? Rev Cardiovasc Med 2004;5 Suppl 3(S14-21).

3. Tutun U, Aksoyek A, Ulus AT, Misirlioglu M, Cicekcioglu F, Ozisik K, Ihsan Parlar A, et al. Gene polymorphisms in patients below 35 years of age who underwent coronary artery bypass surgery. Coron Artery Dis 2006;17(1):35-39.

4. Tsai CT, Hwang JJ, Ritchie MD, Moore JH, Chiang FT, Lai LP, Hsu KL, et al. Renin-angiotensin system gene polymorphisms and coronary artery disease in a large angiographic cohort: detection of high order gene-gene interaction. Atherosclerosis 2007;195(1):172-180.

5. Ehlers MR, Riordan JF. Angiotensin-converting enzyme: new concepts concerning its biological role. Biochemistry 1989;28(13):5311-5318.

6. Huang XH, Rantalaiho V, Wirta O, Pasternack A, Koivula T, Hiltunen TP, Nikkari T, et al. Angiotensin-converting enzyme gene polymorphism is associated with coronary heart disease in non-insulin-dependent diabetic patients evaluated for 9 years. Metabolism 1998;47(10):12581262.

7. Akar N, Aras O, Omurlu K, Cin S. Deletion polymorphism at the angiotensin-converting enzyme gene in Turkish patients with coronary artery disease. Scand J Clin Lab Invest 1998;58(6):491-495. 
8. Isbir T, Yilmaz H, Agachan B, Aydin M, Isbir CS. Association between angiotensin-converting enzyme gene polymorphism and coronary artery disease. IUBMB Life 1999;48(2):205-207.

9. Zhang C, Lopez-Ridaura R, Hunter DJ, Rifai N, Hu FB. Common variants of the endothelial nitric oxide synthase gene and the risk of coronary heart disease among U.S. diabetic men. Diabetes 2006;55(7):2140-2147.

10. Hingorani AD, Liang CF, Fatibene J, Lyon A, Monteith S, Parsons A, Haydock S, et al. A common variant of the endothelial nitric oxide synthase (Glu298-->Asp) is a major risk factor for coronary artery disease in the UK. Circulation 1999;100(14):1515-1520.

11. Hibi K, Ishigami T, Tamura K, Mizushima S, Nyui N, Fujita T, Ochiai H, et al. Endothelial nitric oxide synthase gene polymorphism and acute myocardial infarction. Hypertension 1998;32(3):521-526.

12. Ossei-Gerning N, Mansfield MW, Stickland MH, Wilson IJ, Grant PJ. Plasminogen activator inhibitor-1 promoter $4 \mathrm{G} / 5 \mathrm{G}$ genotype and plasma levels in relation to a history of myocardial infarction in patients characterized by coronary angiography. Arterioscler Thromb Vasc Biol 1997;17(1):33-37.

13. Kario K, Kanai N, Saito K, Nago N, Matsuo T, Shimada $\mathrm{K}$. Ischemic stroke and the gene for angiotensin-converting enzyme in Japanese hypertensives. Circulation 1996;93(9):1630-1633.

14. Margaglione M, Grandone E, Vecchione G, Cappucci G, Giuliani N, Colaizzo D, Celentano E, et al. Plasminogen activator inhibitor-1 (PAI-1) antigen plasma levels in subjects attending a metabolic ward: relation to polymorphisms of PAI-1 and angiontensin converting enzyme (ACE) genes. Arterioscler Thromb Vasc Biol 1997;17(10):2082-2087.

15. Margaglione M, Grandone E, Cappucci G, Colaizzo D, Giuliani N, Vecchione G, d'Addedda M, et al. An alternative method for PAI-1 promoter polymorphism (4G/5G) typing. Thromb Haemost 1997;77(3):605-606.

16. Gardemann A, Fink M, Stricker J, Nguyen QD, Humme J, Katz N, Tillmanns H, et al. ACE I/D gene polymorphism: presence of the ACE D allele increases the risk of coronary artery disease in younger individuals. Atherosclerosis 1998;139(1):153-159.

17. Andersson B, Sylven C. The DD genotype of the angiotensin-converting enzyme gene is associated with increased mortality in idiopathic heart failure. J Am Coll Cardiol 1996;28(1):162-167.

18. Agerholm-Larsen B, Nordestgaard BG, Steffensen R, Sorensen TI, Jensen G, Tybjaerg-Hansen A. ACE gene polymorphism: ischemic heart disease and longevity in 10,150 individuals. A case-referent and retrospective cohort study based on the Copenhagen City Heart Study.
Circulation 1997;95(10):2358-2367.

19. Dzimiri N, Basco C, Moorji A, Meyer BF. Angiotensinconverting enzyme polymorphism and the risk of coronary heart disease in the Saudi male population. Arch Pathol Lab Med 2000;124(4):531-534.

20. Dawson SJ, Wiman B, Hamsten A, Green F, Humphries $\mathrm{S}$, Henney AM. The two allele sequences of a common polymorphism in the promoter of the plasminogen activator inhibitor-1 (PAI-1) gene respond differently to interleukin-1 in HepG2 cells. J Biol Chem 1993;268(15):10739-10745.

21. Margaglione M, Cappucci G, Colaizzo D, Giuliani N, Vecchione G, Grandone E, Pennelli O, et al. The PAI1 gene locus $4 \mathrm{G} / 5 \mathrm{G}$ polymorphism is associated with a family history of coronary artery disease. Arterioscler Thromb Vasc Biol 1998;18(2):152-156.

22. Visanji JM, Seargent J, Tahri D, Croft SA, Makris M, Preston FE, Peake IR, et al. Influence of the -675 4G/5G dimorphism of the plasminogen activator inhibitor 1 promoter on thrombotic risk in patients with factor $\mathrm{V}$ Leiden. Br J Haematol 2000;110(1):135-138.

23. Anvari A, Schuster E, Gottsauner-Wolf M, Wojta J, Huber K. PAI-I 4G/5G polymorphism and sudden cardiac death in patients with coronary artery disease. Thromb Res 2001;103(2):103-107.

24. Mikkelsson J, Perola M, Wartiovaara U, Peltonen L, Palotie A, Penttila A, Karhunen PJ. Plasminogen activator inhibitor-1 (PAI-1) 4G/5G polymorphism, coronary thrombosis, and myocardial infarction in middleaged Finnish men who died suddenly. Thromb Haemost 2000;84(1):78-82.

25. Ridker PM, Hennekens CH, Lindpaintner K, Stampfer MJ, Miletich JP. Arterial and venous thrombosis is not associated with the $4 \mathrm{G} / 5 \mathrm{G}$ polymorphism in the promoter of the plasminogen activator inhibitor gene in a large cohort of US men. Circulation 1997;95(1):59-62.

26. Colombo MG, Andreassi MG, Paradossi U, Botto N, Manfredi S, Masetti S, Rossi G, et al. Evidence for association of a common variant of the endothelial nitric oxide synthase gene (Glu298-->Asp polymorphism) to the presence, extent, and severity of coronary artery disease. Heart 2002;87(6):525-528.

27. Suzuki T, Okumura K, Sone T, Kosokabe T, Tsuboi H, Kondo J, Mukawa H, et al. The Glu298Asp polymorphism in endothelial nitric oxide synthase gene is associated with coronary in-stent restenosis. Int J Cardiol 2002;86(1):71-76.

28. Gomma AH, Elrayess MA, Knight CJ, Hawe E, Fox KM, Humphries SE. The endothelial nitric oxide synthase (Glu298Asp and -786T $>$ C) gene polymorphisms are associated with coronary in-stent restenosis. Eur Heart J 2002;23(24):1955-1962. 